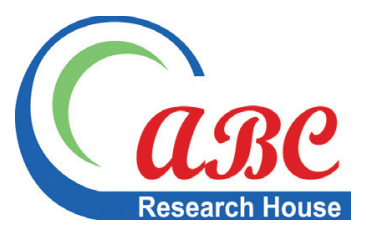

\title{
Financial Soundness of Cement Industry of Bangladesh: An Empirical Investigation Using Z-score
}

\author{
A.N.K Mizan, Md. Mahabbat Hossain \\ Faculty Member, Bangladesh Institute of Bank Management (BIBM), Dhaka, Bangladesh
}

Access this article online
Website:
www.ajtp.us
Volume 1
Number $1 / 2014$
Issue 1
DOI:
Licenced: CC)

E-mail for correspondence: mahabbat@bibm.org.bd

Received: March 02, 2014 Accepted: June 10, 2014 Published: June 30, 2014

\section{ABSTRACT}

For measuring the financial health of a business firm, there are lots of techniques available. But the Altman's Z-score has been proven to be a reliable tool across contexts. Bangladesh cement industry is a unique one because, the industry is producing a higher amount of cement than the local demand having no supply of local raw materials. The main objective of the study is to assess the fundamental financial health of this industry using Z-score model. All listed cement firms are considered in this study. The required information has been collected from the annual reports of the selected companies and from other sources. The study revealed that two firms, Heidelberg cement and Confidence Cement, are financially sound whereas other three are not in a good position. The findings of the study can be useful for the managers to take financial decision, the stockholders to choose investment options and others to look after their interest in the concern cement manufacturers of the country.

Keywords: Cement industry, Financial soundness, Prediction, Z-score

\section{Introduction}

Financial soundness is a matter of great concern for the stakeholders of a business firm. For the owners or shareholders it is very important to understand whether the concerned firm can pay off their required rate of return or not. The creditors will be interested to know the payment capacity of the firm for pricing and collection of credits. Financial sustainability of businesses can be of great importance for the firms doing business with them. It is also important for the management and employees. So, judging the financial capacity of businesses carries enormous information for the institutions and people around it. The measurement of financial soundness shapes the decisions of them.

For measuring the financial health of a business firm, there are lots of techniques available. But the Altman's Z-score has been proven to be a reliable tool across contexts. This model devotes to predict possibilities of bankruptcy of manufacturing concerns. There is evidence that it has $76.9 \%$ accuracy in predicting the bankruptcy of the underlying sample (Begley et al. 1996). In the study, he also finds that the model performs better in USA during the 1980s than the 1990s. Altman (1968) defines five predicted factors that can be used to test the validity of Multivariate model. The model is based on financial ratios. Using financial ratios to predict bankruptcy can be accurate up to $90 \%$ (Chen and Shemerda, 1981).

Bangladesh cement industry is a unique one. Because, the industry is producing a higher amount of cement than the local demand although there is no supply of local raw materials. In addition to that, there is very stiff, and unhealthy competition exists in the industry. On the other hand, the firms are producing almost same quality cement. So, complete dependency on the imported raw materials and unhealthy competition make the companies vulnerable in terms of financial sustainability. So it is a matter of great concern to assess the financial health of the firms in the industry and predict the bankruptcy possibility.

In this context, the study is a very important one to provide the right information to the stakeholders about the financial 
health of the companies under the cement industry of Bangladesh. With this view, the objectives of the study are one, to assess the fundamental financial health of the cement industry of Bangladesh; and two, to identify the bankruptcy possibility of the selected industry on the basis of Z-score.

The first section of the report includes introduction and objectives of the study. The next section presents methodology of the study and review of relevant prior literatures is presented in part three. Section four portrays results and findings followed by conclusion in section five.

\section{Methodology of the Study}

The study focuses on the cement industry of Bangladesh. There are two stock exchanges in Bangladesh-Dhaka Stock Exchange (DSE) and Chittagong Stock Exchange (CSE). In 2010, five cement companies were listed on DSE and CSE (Table 1). Thus, all inclusive sampling technique is followed for the current study. The required information has been collected from the annual reports of the selected companies. As the biggest and oldest stock exchange of Bangladesh, we consider the market price of DSE. Other data have been collected from different other sources including the internet and dailies of the country. The hypothesis we have taken is that;

$\mathrm{H}_{0}$ : The values of $\mathrm{X}_{1}, \mathrm{X}_{2}, \mathrm{X}_{3}, \mathrm{X}_{4}$, and $\mathrm{X}_{5}$ are uniform in the sample units.

For analyzing the performance of the company fundamentals one way ANOVA ${ }^{1}$ and for predicting bankruptcy, the Altman $\mathrm{Z}$ score have been used. Through the following equation possibility of bankruptcy of the industry has been judged;

$$
\mathrm{Z}=1.2 \mathrm{X}_{1}+1.4 \mathrm{X}_{2}+3.3 \mathrm{X}_{3}+.6 \mathrm{X}_{4}+.999 \mathrm{X}_{5}
$$

Table 1: Listed cement companies of Bangladesh

\begin{tabular}{|c|c|c|c|c|c|}
\hline$S L$ & Name & $\begin{array}{l}\text { Market } \\
\text { category }\end{array}$ & $\begin{array}{l}\text { Year of } \\
\text { listing } \\
\text { on DSE }\end{array}$ & $\begin{array}{l}\text { Year of } \\
\text { listing } \\
\text { on CSE }\end{array}$ & Year end \\
\hline 1. & $\begin{array}{l}\text { Heidelbergcement } \\
\mathrm{Bd} \text {. (HCL) }\end{array}$ & A & 1989 & 1995 & $\begin{array}{l}\text { December } \\
31^{\text {st }}\end{array}$ \\
\hline 2. & $\begin{array}{l}\text { Confidence } \\
\text { Cement (CCL) }\end{array}$ & A & 1995 & 1995 & $\begin{array}{l}\text { December } \\
31^{\text {st }}\end{array}$ \\
\hline 3. & $\begin{array}{l}\text { Meghna Cement } \\
\text { Mills (MCL) }\end{array}$ & A & 1995 & 1996 & $\begin{array}{l}\text { December } \\
31^{\text {st }}\end{array}$ \\
\hline 4. & $\begin{array}{l}\text { Aramit Cement } \\
(A C L)\end{array}$ & A & 1998 & 1998 & $\begin{array}{l}\text { December } \\
\text { 31st }\end{array}$ \\
\hline 5. & $\begin{array}{l}\text { Lafarge Surma } \\
\text { Cement (LCL) }\end{array}$ & Z & 2003 & 2003 & $\begin{array}{l}\text { December } \\
31^{\text {st }}\end{array}$ \\
\hline
\end{tabular}

Source: DSE (2010) and www.cse.com.bd, retrieved on February 6, 2012

${ }^{1}$ A One-Way Analysis of Variance is a way to test the equality of three or more means at one time by using variances. The null hypothesis will be that all population means are equal, the alternative hypothesis is that at least one mean is different. The decision will be to reject the null hypothesis if the test statistic from the table is greater than the $\mathrm{F}$ critical value
Where,

$\mathrm{X}_{1}=\mathrm{NWC} / \mathrm{TA}$ [It is the ratio between the Net Working Capital (NWC) to Total Asset (TA) of the firm. This ratio measures the state of liquid assets of the organization in respect to the total asset. The value of this ratio indicates the firm's capacity to pay the immediate or short-term obligation of the business];

$\mathrm{X}_{2}=\mathrm{ARE} / \mathrm{TA}$ [Accumulated Retained Earnings (ARE) to Total Asset (TA) is the ratio that measures the accumulated profitability of the business. Usually, business retains profit if it has a good forecast of investment opportunities. In case of financially sound business organization the ratio will be higher];

$\mathrm{X}_{3}=\mathrm{EBIT} / \mathrm{TA}$ [This is the ratio of Earnings Before Interest and Taxes (EBIT) to Total Asset (TA). It a measure if efficiency of an organization by separating the leverages. The value of this ratio signifies the capacity of the firm to generate sufficient earnings to pay off its interest payment obligation. The lower value of the ratio indicates the lower capacity of the firm to pay the interest against borrowing];

$\mathrm{X}_{4}=\mathrm{MVE} / \mathrm{BVD}$ [This is the ratio of Market Value of Equity (MVE) to Book Value of Debt (BVD). It injects the market force in the prediction model as the reality is that there is direct impact of a firm's financial health on the price of shares in the market]; and

$\mathrm{X}_{5}=\mathrm{S} / \mathrm{TA}$ [Sales (S) to Total Asset (TA) is the measure of the firm's efficiency in converting its asset into sales. The higher value provides evidence of better capacity of the organization to generate revenue from the present asset based].

The bankruptcy possibility of a company depends on the value obtained by using the formula. The following will be applicable for the values of $\mathrm{Z}$-score:

if, $\mathrm{Z}>2.99$, the business is financially sound and there is least probability that the firm will face financial distress;

if, $\mathrm{Z}<1.80$, there is a high probability that the business will face financial distress in near future and the business may need desperate measures (such as mergers) to survive in the market; and

if, $1.8<\mathrm{Z}<2.99$, the firm falls in the gray area that means there is less probability that the firm will face financial distress in the near future.

\section{Literature Review}

It is argued that in so far as bankruptcy is due to unforeseeable events and therefore, it cannot be predicted (Morris 1998). On the other hand, there are several researchers (e.g., Altman 1968; Zmijewski 1984; Kida 1998; Shirata 1998; Shumway 2001, etc.) who use some models for predicting bankruptcy. Among others, corporate bankruptcy prediction model developed by Altman in 1968 is the most accepted and widely used tool (Mizan, Amin and Rahman 2011). Conversely, some researchers (e.g., Chava 
and Jarrow 2004; Addullah et al. 2008, etc.) proved that some other models are more accurate than Altman's model. In the following paragraphs, we will present some relevant literatures.

Altman (1968) noted that ratios measuring profitability, liquidity and solvency prevailed as the most significant indicators, but the order of their importance is not clear. So, multiple discriminant analysis was used by Altman (1968) for measuring soundness and prediction of bankruptcy of the firms. In this study, the initial sample was sixty-six firms to establish a function that the best discriminates between companies in two mutually exclusive groups: bankrupt and non-bankrupt firms. The developed model was extremely accurate in classifying $95 \%$ of the total sample correctly. On the basis of findings, he concluded that the bankruptcy prediction model is an accurate forecaster of failure up to two years prior to bankruptcy. The ratios used in this model are working capital/total assets, retained earnings/ total assets, EBIT/total assets, market value equity/total debts and sales to total assets. Shirata (1998) developed an alternative model for bankruptcy prediction. He used four variables like, e.g., (i) retained earnings/total assets, (ii) (current period liabilities and shareholders equity/previous period liability and shareholders equity)-1, (iii) interest and discount expense/(short term borrowings + long term borrowings + corporate bond + convertible bond + note receivable discounted), and (iv) note payable + accounts payable $) \times 12 /$ Sales. He stated that the model can predict bankruptcy with more than $86.14 \%$ accuracy regardless of industry and size.

The Altman Z score model is used in different countries for predicting bankruptcy. Al-Rawi, Kiani and Vedd (2008) used the Altman z-score analysis to predict a firm's insolvency. They followed case study method and selected "Jordan Establishment for Marketing Durable goods" as a case. The z-score of the firm for the given period (2002-2004) was less than 1.81. They have made a comment that the firm has increased its debt and will be facing bankruptcy in the near future. Gerantonis Vergos and Christopoulos (2009) investigated whether Z-score models can predict bankruptcies for a period up to three years earlier. Results showed that Altman model performed well in predicting failures. They concluded that the results can be used by company management for financing decisions, by regulatory authorities and by portfolio managers in stock selection. Ramaratnam and Jayaraman (2010) measured financial soundness of Indian steel industry by using $\mathrm{Z}$ score model. The study was based on five years' data (2006-2010) of five firms of the steel industry. Their study revealed that all the selected companies are financially sound during the study period. Alkhatib and Al Bzour (2011) conducted a study to report the effect of financial ratios in bankruptcy prediction in Jordanian listed companies through the use of Altman and Kida models. The study sample included sixteen non-financial service and industrial companies for the years 1990-2006. According to their results, out of the two models Altman's model has an advantage in company bankruptcy prediction, with a $93.8 \%$ average predictive ability of the five years prior to the liquidation incident, while the average for Kida's model is 69\%. They suggested that the Jordanian listed companies should at least apply one of these models with high credibility for predicting corporate bankruptcy.
In Bangladesh Z score model has also been used in different studies. Chowdhury and Barua (2009) applied Z score model to the $\mathrm{Z}$ category shares traded in DSE to judge financial distress risk of each share. They used 53 companies' data of the years 2000-2005 to calculate Z-score. They argued that the Altman's $\mathrm{Z}$ score model, though may not be fully applicable for companies in Bangladesh, yet proves its strong validity and correctness in predicting distressful status of the $Z$ category companies. Mizan, Amin, and Rahman (2011) conducted a study for the prediction of bankruptcy of the pharmaceutical industry in Bangladesh. They used the Altman Z-score Model for this purpose where sample size was six leading companies of this industry. Their study reveals some valuable findings like, two firms are found financially sound having no bankruptcy possibility in the near future and other companies are found to be unsatisfactory and they have a significant likelihood of facing financial distress in the near future. They also stated that market value of equity of most of the firms is not reflecting the fundamentals of the respective companies.

\section{Results and Findings}

Table 2 presents the ratios of the NWC (Net Working Capital) to TA (Total Asset). The ratio is very important to understand the liquidity position of the selected firms. By nature, the cement manufacturers require huge working capital to carry out smooth business operation. Among the firms, the HCL (Heidelberg cement) has the highest mean value of the ratio, indicating better working capital management practices within the organization. The other two companies that are the CCL (Confidence Cement) and MCL (Meghna Cement Mills) have positive mean values of the ratio but these are below $10 \%$, indicating marginal condition in managing the working capital. The NWC/TA ratio also indicates the capacity of an organization to meet up the immediate short term obligations or the current liabilities. The rest two firms ACL (Aramit Cement) and LCL (Lafarge Surma Cement) are showing negative values of the ratio, providing the evidence of working capital shortfall or inability to pay off short term liabilities such as payment to suppliers or short term creditors. Industry average is also negative over the period due to negative ratios of these two firms.

The ANOVA table (Table 3) of the NWC/TA ratio is showing convincing result as the calculated $\mathrm{F}$ value (22.1735) is far higher than the critical F value (2.866081). So the null hypothesis can be rejected that the values of the variable are uniform in nature.

The ratio of ARE (Accumulated Retained Earnings) to TA (Total Asset) is a very important parameter to assess the fundamental soundness of a business firm. Calculation (Table 4) is showing that three of the selected five companies have negative average ratio. The ratios signify that they have incurred losses during the observed period. The HCL has a significant higher average value of the ratio that is $38.36 \%$. The other company that is MCL has positive, but insignificant $(2.5 \%)$, average value of ARE/TA ratio. But the variation of the ratio is low across the selected companies; it ranges from about $1 \%$ to $14 \%$. 
The summary of ANOVA is presented in Table 5. The result of ANOVA is showing that the calculated $\mathrm{F}$ value is higher than the critical value of $\mathrm{F}$ and indicating that the null hypothesis can be rejected. So, the values of the variable are not uniform within the sample unit.

Table 6 shows that HCL has the highest mean value of the EBIT (Earning before Interest and Tax) to TA (Total Assets) ratio $(19.34 \%)$ among the companies. This ratio measures the efficiency of business in converting its assets into sales. The next one is ACL showing the mean ratio of $12.49 \%$. But the HCL has the lower variation in the ratio indicating a very stable profit generating capacity. The lowest value is with LCL (4.69\%). As it is the newest one in the industry, it is struggling to move with the other companies of the industry. The EBIT/TA ratio of CCL is not competitive. Table 7 is showing the result of one-way ANOVA of the EBIT/TA ratio. The Calculated $F$ value is higher than the $\mathrm{F}$ critical value, so we can reject the null hypothesis of equal means. That is the means of the ratio of the selected companies are not uniform in the sample units.

Table 2: The ratio of NWC/TA of the selected companies

\begin{tabular}{|c|c|c|c|c|c|c|c|}
\hline Company/year & $\mathrm{HCL}$ & CCL & MCL & $A C L$ & LCL & Mean & SD \\
\hline 2006 & $(0.0505)$ & 0.0624 & $(0.0267)$ & $(0.4163)$ & $(0.1627)$ & $(0.1187)$ & 0.1847 \\
\hline 2007 & 0.0126 & 0.1103 & 0.0503 & $(0.4278)$ & $(0.2366)$ & $(0.0982)$ & 0.2267 \\
\hline 2008 & 0.1088 & 0.0331 & 0.1745 & $(0.3883)$ & $(0.2591)$ & $(0.0662)$ & 0.2447 \\
\hline 2009 & 0.2851 & 0.0822 & 0.1513 & $(0.2465)$ & $(0.3083)$ & $(0.0072)$ & 0.2581 \\
\hline 2010 & 0.3617 & 0.0692 & 0.1079 & $(0.2179)$ & $(0.4402)$ & $(0.0239)$ & 0.3105 \\
\hline Mean & 0.1435 & 0.0715 & 0.0915 & $(0.3393)$ & $(0.2814)$ & & \\
\hline SD & 0.1758 & 0.0282 & 0.0813 & 0.0994 & 0.1031 & & \\
\hline
\end{tabular}

Source: Researchers' own analysis

Table 3: One-way ANOVA of the NWC/TA ratio

\begin{tabular}{lccccc}
\hline Source of variation & SS & df & MS & F & F crit \\
\hline Between groups & 1.043291 & 4 & 0.26082 & 22.1735 \\
Within groups & 0.235257 & 20 & 0.01176 & $2.08 \mathrm{E}-07$ \\
Total & 1.278547 & 24 & & \\
\hline
\end{tabular}

Source: Researchers' own analysis

Table 4: The ratio of ARE/TA of the selected companies

\begin{tabular}{|c|c|c|c|c|c|c|c|}
\hline Company/year & $\mathrm{HCL}$ & CCL & MCL & ACL & LCL & Mean & SD \\
\hline 2006 & 0.2788 & 0.0015 & $(0.0206)$ & $(0.3965)$ & $(0.0836)$ & $(0.0441)$ & 0.2412 \\
\hline 2007 & 0.3227 & 0.0052 & 0.0200 & $(0.3402)$ & $(0.1321)$ & $(0.0249)$ & 0.2422 \\
\hline 2008 & 0.3601 & $(0.0197)$ & 0.0276 & $(0.2662)$ & $(0.0925)$ & 0.0019 & 0.2292 \\
\hline 2009 & 0.4607 & 0.0034 & 0.0405 & $(0.1379)$ & $(0.0888)$ & 0.0556 & 0.2374 \\
\hline 2010 & 0.4959 & 0.0057 & 0.0574 & $(0.0344)$ & $(0.1772)$ & 0.0695 & 0.2538 \\
\hline Mean & 0.3836 & $(0.0008)$ & 0.0250 & $(0.2350)$ & $(0.1149)$ & & \\
\hline SD & 0.0919 & 0.0107 & 0.0292 & 0.1481 & 0.0398 & & \\
\hline
\end{tabular}

Source: Researchers' own analysis

Table 5: One-way ANOVA of the ARE/TA ratio

\begin{tabular}{lccccc}
\hline Source of variation & SS & df & MS & F & $P$-value \\
\hline Between groups & 1.077856 & 4 & 0.26946 & 40.8968 & $2.33 \mathrm{E}-09$ \\
Within groups & 0.131777 & 20 & 0.00659 & & 2.866081 \\
Total & 1.209633 & 24 & & & \\
\hline Sourit & & & & \\
\hline
\end{tabular}

Source: Researchers' own analysis

Table 6: The ratio of EBIT/TA of the selected companies

\begin{tabular}{lccccccc}
\hline Company/year & $\mathrm{HCL}$ & $\mathrm{CCL}$ & $\mathrm{MCL}$ & $\mathrm{ACL}$ & $\mathrm{LCL}$ & $\mathrm{Mean}$ & $\mathrm{SD}$ \\
\hline 2006 & 0.1752 & 0.0766 & 0.0994 & 0.0716 & $(0.0093)$ & 0.0827 & 0.0661 \\
2007 & 0.1837 & 0.0869 & 0.0969 & 0.1055 & $(0.0056)$ & 0.0935 & 0.0674 \\
2008 & 0.1657 & $(0.0115)$ & 0.0458 & 0.0485 & 0.1112 & 0.0719 & 0.0680 \\
2009 & 0.2347 & 0.0793 & 0.0844 & 0.2269 & 0.1381 & 0.1527 & 0.0750 \\
2010 & 0.2077 & 0.0054 & 0.0723 & 0.1722 & $(0.0001)$ & 0.0915 & 0.0951 \\
Mean & 0.1934 & 0.0474 & 0.0798 & 0.1249 & 0.0469 & \\
SD & 0.0279 & 0.0465 & 0.0219 & 0.0737 & 0.0717 & \\
\hline
\end{tabular}

Source: Researchers' own analysis 
The following table (Table 8) is representing the ratio of MVE (Market Value of Equity) to BVD (Book Value of Debt). For all the companies, the ratios are very high during the year 2009 and 2010 , specially, the year 2010. The industry average of this ratio was 0.9968 in 2006 whereas it is 6.4367 in 2010 . So, the variation is high. CCL has the highest average value of the ratio (5.0337) and it shows the highest variation $(\mathrm{SD}=6.1194)$. The ratio of MVE/BVD indicates the confident of the common stockholders on the performance of the company. But the one way ANOVA result that that the value of the calculated $\mathrm{F}$ value is marginally higher than the critical F value (Table 9) while it is different in case of other ratios. Although the null hypothesis can be rejected on the basis of the result but the values of are showing some degree of uniformity. The reason could be the impact of an increase of the price level of shares in the stock exchanges.

Table 10 depicts the ratio of Sales to Total Asset (S/TA) of the selected companies. It is the ratio that indicates the capacity of the company to generate sales revenue by using the available assets of the company. The higher ratio indicates better efficiency of the company to generate revenue by utilizing assets. It can be found that three companies, as HCL (1.1478),
MCL (1.3080) and ACL (1.1266), are performing almost in the same level during the observed period. Again the highest value remains with the HCL and the others two are following it. But, the other two companies, CCL (0.8134) and LCL (0.2503) are not going with the industry. They have lower capacity in generating sales revenue. It is noted that the industry average of this ratio is consistent over the years.

Table 11 is showing the results of the ANOVA performed on the $\mathrm{S} / \mathrm{TA}$ ratio of the cement industry of Bangladesh. The calculated $\mathrm{F}$ value is significantly higher than the critical value of $\mathrm{F}$ so, and the null hypothesis can be rejected. Thus, it is concluded that the values are not uniform within the sample units.

Table 12 presents the calculated Z score of the selected cement manufacturers of the country. If we look into the values, the HCL is showing a very consistent performance during the period, and the average value of $Z$ score stands at 5.133. The next best company is CCL which has average Z score of 4.0737, although it has faced some difficulties in the year of 2006 and 2008. But the company has achieved significantly higher value of $\mathrm{Z}$ score (9.7503) in the year of 2010. So, it can be concluded that HCL

Table 7: One-way ANOVA of the EBIT/TA ratio

\begin{tabular}{lccccc}
\hline Source of variation & SS & df & MS & F & F crit \\
\hline Between groups & 0.076676 & 4 & 0.01917 & 6.85054 \\
Within groups & 0.055963 & 20 & 0.0028 & 2.866081 \\
Total & 0.132639 & 24 & & \\
\hline
\end{tabular}

Source: Researchers' own analysis

Table 8: The ratio of MVE/BVD of the selected companies

\begin{tabular}{|c|c|c|c|c|c|c|c|}
\hline Company/year & $\mathrm{HCL}$ & CCL & MCL & $\mathrm{ACL}$ & LCL & Mean & SD \\
\hline 2006 & 1.9168 & 0.7061 & 0.3361 & 0.2265 & 1.7984 & 0.9968 & 0.8068 \\
\hline 2007 & 2.9650 & 1.7113 & 0.3518 & 0.4271 & 2.0436 & 1.4998 & 1.1131 \\
\hline 2008 & 2.6769 & 1.1499 & 0.3709 & 0.3985 & 2.2014 & 1.3595 & 1.0475 \\
\hline 2009 & 5.9099 & 6.4176 & 1.1101 & 1.2137 & 3.7938 & 3.6890 & 2.5083 \\
\hline 2010 & 8.5220 & 15.1838 & 2.6486 & 2.6222 & 3.2067 & 6.4367 & 5.4816 \\
\hline Mean & 4.3981 & 5.0337 & 0.9635 & 0.9776 & 2.6088 & & \\
\hline SD & 2.7598 & 6.1194 & 0.9975 & 0.9954 & 0.8520 & & \\
\hline
\end{tabular}

Source: Researchers' own analysis

Table 9: One-way ANOVA of the MVE/BVD ratio

\begin{tabular}{lccccc}
\hline Source of variation & SS & df & MS & F & P-value \\
\hline Between groups & 71.37009 & 4 & 17.8425 & 3.86733 & 0.155692 \\
Within groups & 191.1023 & 20 & 9.55511 & & 2.866081 \\
Total & 262.4724 & 24 & & & \\
\hline
\end{tabular}

Source: Researchers' own analysis

Table 10: The ratio of S/TA of the selected companies

\begin{tabular}{lccccccc}
\hline Company/year & HCL & CCL & MCL & ACL & LCL & Mean & SD \\
\hline 2006 & 1.2092 & 0.9455 & 1.4149 & 1.2060 & 0.0090 & 0.9569 & 0.5554 \\
2007 & 1.0909 & 1.0020 & 0.9833 & 1.1519 & 0.1396 & 0.8736 \\
2008 & 1.0850 & 1.0656 & 1.1202 & 1.1664 & 0.3509 & 0.9576 \\
2009 & 1.1951 & 0.5222 & 1.4390 & 1.1738 & 0.4363 & 0.9533 \\
2010 & 1.1586 & 0.5316 & 1.5828 & 0.9348 & 0.3157 & 0.9047 \\
Mean & 1.1478 & 0.8134 & 1.3080 & 1.1266 & 0.2503 & 0.4461 \\
SD & 0.0577 & 0.2650 & 0.2474 & 0.1090 & 0.1728 & \\
\hline
\end{tabular}

Source: Researchers' own analysis 
Table 11: One-way ANOVA of the S/TA ratio

\begin{tabular}{lccccc}
\hline Source of variation & SS & df & MS & F & P-value \\
\hline Between groups & 3.5229 & 4 & 0.88073 & 24.9518 & $1.57 \mathrm{E}-07$ \\
Within groups & 0.705941 & 20 & 0.0353 & & 2.866081 \\
Total & 4.228842 & 24 & & & \\
\hline
\end{tabular}

Source: Researchers' own analysis

Table 12: The Z-score of the selected companies

\begin{tabular}{|c|c|c|c|c|c|c|c|}
\hline Company/year & $\mathrm{HCL}$ & $\mathrm{CCL}$ & $\mathrm{MCL}$ & $\mathrm{ACL}$ & $\mathrm{LCL}$ & Mean & SD \\
\hline 2006 & 3.2660 & 1.6979 & 1.8822 & 0.5223 & 0.7449 & 1.6227 & 1.0903 \\
\hline 2007 & 3.9420 & 2.4543 & 1.6017 & 0.7655 & 0.8783 & 1.9283 & 1.3127 \\
\hline 2008 & 3.8714 & 1.7287 & 1.7407 & 0.7256 & 1.5979 & 1.9328 & 1.1626 \\
\hline 2009 & 6.5014 & 4.7375 & 2.6205 & 2.1607 & 2.6735 & 3.7387 & 1.8375 \\
\hline 2010 & 8.0844 & 9.7503 & 3.6188 & 2.7660 & 1.4629 & 5.1365 & 3.5845 \\
\hline Mean & 5.1330 & 4.0737 & 2.2928 & 1.3880 & 1.4715 & & \\
\hline SD & 2.0664 & 3.4070 & 0.8392 & 1.0089 & 0.7650 & & \\
\hline
\end{tabular}

Source: Researchers' own analysis

Table 13: One-way ANOVA of the Z-score

\begin{tabular}{lccccc}
\hline Source of variation & SS & df & MS & F & P-value \\
\hline Between groups & 55.27829 & 4 & 13.8196 & 3.79984 & 0.018651 \\
Within groups & 72.73769 & 20 & 3.63688 & & 2.866081 \\
Total & 128.016 & 24 & & & \\
\hline
\end{tabular}

Source: Researchers' own analysis

and CCL have very low or no possibility of financial distress in a near future. On the other hand, average $Z$ score of two companies, ACL (1.338) and LCL (1.4715), are below 1.8. None of the observed years' $Z$ score of these two companies is indicating sound financial condition. These companies are at the verge of financial distress. So, the managements of the companies are in need of restructuring decision - within or outside of the organization. The financial condition of those companies is a matter of great concern for the stockholders and other stakeholders. The average Z score of MCL is 2.2928 which indicates the "zone of ignorance". The company has faced some financial difficulties during the observed period. Though, the Z score in the year 2010 is good enough (3.6188) to indicate financial soundness. This company was in a risky zone in the year 2006 to 2008.

Industry average $\mathrm{Z}$ score in 2006, 2007 and 2008 are 1.6227, 1.9283 and 1.9328 respectively which are not indicating financial soundness. None but HCL is in sound financial position in these years. However, average Z score in 2009 and 2010 are more than 2.99 which indicate financial soundness and least probability of financial distress. So, at present the cement industry is financially sound though some firms are in the verge of bankruptcy. Investors should consider this matter seriously.

The ANOVA of the calculated Z scores of the selected companies is depicted in Table 13. The null hypothesis can be rejected as the calculated value of $\mathrm{F}$ is higher than the critical value of $F$ (3.79984 > 2.866081). So, the $Z$ scores are not uniform among the sample units.

\section{Conclusion}

The fundamental financial health of a business firm is the main concern for the stakeholders. On the basis of the financial soundness, they take a decision regarding their possible involvement with a particular firm. The Altman Z score is the best measurement that can shape the decision of the stakeholders. The current study has been conducted to assess the financial health of the firms under the cement industry of Bangladesh. The study revealed that among the five firms, two (HCL and CCL) are financially sound as they have higher Z score than the benchmark (2.99). Another firm that is MCL is in the gray area that is the firm is financially sound, but the management requires special attention to improve the financial health of the organization. Otherwise, the firm may face financial distress in the long run. The other two firms are at serious risk of financial distress. Thus, the management should take necessary steps to reverse the situation, and the general investors should be careful in investing in the stocks of these companies. So, the findings of the study can be useful for the managers to take financial decision, the stockholders to choose investment options and others to look after their interest in the concern cement manufacturers of the country.

\section{References}

Abbas, O. and Rashid, A. (2011). "Modeling Bankruptcy Prediction for Non-Financial Firms: The Case of Pakistan", MPRA Paper No. 28161, available at http://mpra.ub.uni-muenchen.de/28161, retrieved on January 26, 2012

Addullah, N.A.H., Halim, A., Ahmad, H. and Rus, R.M. (2008). “Predicting Corporate Failure of Malaysia's Listed Companies: Comparing Multiple Discriminant Analysis, Logistic Regression and the Hazard Model", International Research Journal of Finance and Economics, 15: 201-217.

Alkhatib, K. and Al Bzour, A.E. (2011). “Predicting Corporate Bankruptcy of Jordanian Listed Companies: Using Altman and Kida Models", International Journal of Business and Management, 6(3): 208-215.

Al-Rawi, K, Kiani, R. and Vedd, R.R. (2008). "The Use of Altman Equation for Bankruptcy Prediction in an Industrial Firm (Case Study)", International Business \& Economics Research Journal, 7(7): 115-127. 
Altman, E.I. (1968). "Financial Ratios, Discriminant Analysis and the Prediction of Corporate Bankruptcy", The Journal of Finance, 23(4): 589-609.

Begley J., Ming J. and Watts S. (1996). "Bankruptcy classification errors in the 1980s: An empirical analysis of Altman's and Ohlson's models". Review of Accounting Studies, 1(4):267-284.

Bongini, P., Ferri, G. and Hahm, H. (2000). "Corporate Bankruptcy in Korea: Only the Strong Survive?". The Financial Review, 35: 31-50.

Chava, S. and Jarrow, R.A. (2004). "Bankruptcy Prediction with Industry Effects", Review of Finance, 8: 537-569.

Chen K. H. and Thomas A. Shimerda. (1981). "An Empirical Analysis of Useful Financial Ratios", Financial Management, 10(1): 51-60.

Chowdhury, A. and Barua, S. (2009). "Rationalities of z-category shares in Dhaka Stock Exchange: are they in financial distress risk?", BRAC University Journal, 1(1): 45-58.

Gerantonis, N., Vergos, K. and Christopoulos, A.G. (2009). "Can Altman Z-score Models Predict Business Failures in Greece?", Research Journal of International Studies, 12: 21-28.

Kida, C.Y. (1998). "Financial Ratios as Predictors of Bankruptcy in Japan: An Empirical Research", Journal of Finance, 123: 589-609, cited in Alkhatib, K. and Al Bzour, A.E. (2011). “Predicting Corporate Bankruptcy of Jordanian Listed Companies: Using Altman and Kida Models", International Journal of Business and Management, 6(3): 208-215.

Mizan, A.N.K., Amin, M.R. and Rahman, T. (2011). "Bankruptcy Prediction by Using the Altman Z-score Model: An Investigation of the Pharmaceutical Industry in Bangladesh", Bank Parikrama, 36(2-4): 33-56.

Morris, R. (1998). “Bankruptcy Prediction Models: Just How Useful Are They?", Credit Management, pp. 43-45, cited in Al-Rawi, K, Kiani, R. and Vedd, R.R. (2008). "The Use of Altman Equation for Bankruptcy
Prediction in an Industrial Firm (Case Study)", International Business \& Economics Research Journal, 7(7): 115-127.

Ramaratnam, M.S. and Jayaraman, R. (2010). "A study on measuring the financial soundness of select firms with special reference to Indian steel industry - An empirical view with Z score", Asian Journal of Management Research, Online Open Access publishing platform for Management Research, pp. 724-735.

Shirata, C.Y. (1998). "Financial Ratios as Predictors of Bankruptcy in Japan: An Empirical Research", Paper presented in the Second Asian-Pacific Interdisciplinary Research in Accounting Conference Program (APIRA98) held on $4^{\text {th }}-6^{\text {th }}$ August, 1998, available at http:// www3.bus.osaka-cu.ac.jp/apira98/archives/pdfs/31.pdf, retrieve on January 25, 2012

Shumway, T. (2001). “Forecasting bankruptcy more accurately: A simple hazard model", Journal of Business, 74(1): 101-124, cited in Chava, S. and Jarrow, R.A. (2004). "Bankruptcy Prediction with Industry Effects", Review of Finance, 8: 537-569.

Zmijewski, M. E. (1984). "Methodological issues related to the estimation of financial distress prediction models", Journal of Accounting Research, 22(1): 59-82, cited in Chava, S. and Jarrow, R.A. (2004), "Bankruptcy Prediction with Industry Effects", Review of Finance, 8: 537-569.

How to Cite: Mizan AN and Hossain MM. 2014. Financial Soundness of Cement Industry of Bangladesh: An Empirical Investigation Using Z-score American Journal of Trade and Policy, 1, 16-22.

Source of Support: Nil, Conflict of Interest: None declared. 